\title{
ICT diffusion and the finance-growth nexus: a panel analysis on ECOWAS countries
}

\author{
Ahmed S. Alimi ${ }^{1 *}$ and Idris A. Adediran ${ }^{1,2}$
}

\begin{abstract}
In this study, we rely on the extension of the endogenous growth theory to consider the role of ICT diffusion in the finance-growth nexus theoretically informed via the supply-leading and demand-following theses. Motivated by current realities highlighting the significance of information and communication technologies (ICTs) to modern societies, the study evaluates the foregoing research objective in ECOWAS countries over the 2005-2016 period based on the justification of the ICT diffusion into the ECOWAS region around the early 2000s. Innovatively, the study constructs an ICT diffusion index covering fixed telephone lines, mobile cellular subscription and Internet penetration as relevant media for ICT dispersion. We adopt the pooled mean group estimator on a dynamic panel ARDL model for robust analysis of the subject matter. We find that financial development (its main and alternative measure) alone inhibits growth of ECOWAS countries, but its interaction with ICT diffusion promotes economic growth in the region. The implication of our research findings for the West African region is that financial sector development efforts have to be strengthened by investment in ICT infrastructure, improved Internet penetration and further integration of electronic finance policies.
\end{abstract}

Keywords: ICTs, Financial development, Economic growth, ECOWAS, PMG estimator

JEL Classification: G20, O33, O40

\section{Introduction}

A considerably large number of theoretical and empirical studies have attempted to recognize the main drivers of economic growth, and the level of financial development has been identified as such (see [7]. The theoretical underpinning of the financial development and economic growth nexus can be traced to the works of Schumpeter [68], Gurley and Shaw [26], Goldsmith [24], McKinnon [40] and Shaw [69]. Also, the endogenous growth theory, in conjunction with the McKinnon-Shaw hypothesis, also stressed the importance of financial development for long-term economic growth through the effect of financial sector services on capital accumulation and technological innovation (see [2]). Such financial services include mobilizing deposits, gathering portfolio

\footnotetext{
*Correspondence: ahmedshina8@gmail.com

${ }^{1}$ Department of Economics, Obafemi Awolowo University, Ile-Ife, Osun State, Nigeria

Full list of author information is available at the end of the article
}

information and resource allocation, evaluating managers and maintaining corporate control, and fostering risk reduction. However, there are still theoretical ambiguities and empirical inconclusiveness in the nexus (see [5]).

In view of these anomalies, the present study accentuates the role of ICT in complementing financial development towards achieving economic growth. Information and communication technology (ICT) is a variety of technical tools and resources used to communicate and to develop, disseminate, store and manage information (see [43]). It represents a collection of technologies and applications, enabling electronic processing, storing, retrieval and transfer of information to a wide variety of users [14]. It also enables the exchange of data across multiple locations and aids decentralized information processing and contributes potentially to the emergence of new business and company cooperation models that rely on the spatial exchange of large batches of information, which boosts processes of competition and innovation (according to 
Salahuddin and Gow [65]). These IT tools offer new ways of information exchange and business transactions and change the nature of the financial and other service sectors (see [43]).

The significance of ICT for development is obvious. For instance, ICT diffusion, with the Internet at its core, has been linked with the world's profound transformation into an information society [32]. Elene [19] sees ICT as being one of the world's fastest growing industries with ICT job creation in the US expected to grow by $22 \%$ up to 2020; a $10 \%$ increase in broadband penetration in emerging markets associated with GDP growth of 1.4\%; and many businesses across the world now have online presence and are able to reach out to customers and compete for market share. ICT penetration into the financial system is being felt in the form of introduction of ICT gadgets such as automated teller machine (ATM), electronic fund transfer (EFT), clearing house automated payments (CHAPs), electronic purse (E-PURSE), automated check sorter (ACS) and point of sale electronic and transfer (EFTPOS) that made financial transactions easy and convenient (see [48]). These have paved way for automation, minimal banking hall transactions, less hectic procedures and less congestion in banking halls in carrying out transactions.

In relation to economic growth, ICT influences economic growth and business value and enhances innovation through diffusion processes, usage practices and commercial success [27]. Dimelisa and Papaioannou [17] have linked the new information economy of the past decades to increased ICT diffusion and higher productivity gains and increased growth. Michael et al. [41] anticipated that ICT skills will be at the core of the required skills in the near future, where the incorporation of ICT literacy will be essential to the development of learning skills, difficulty management, problem-solving and critical, innovative and systemic thinking towards the goal of developing cognitive and problem-solving skills.

Theoretically, there are three channels through which ICT stimulates economic growth (see [32]). The first channel of ICT-induced growth is by its fostering innovation and diffusion of knowledge from developed countries to developing countries; the second channel of it is by improving the quality of firm and household decisionmaking, thereby leading to strengthening resource allocation efficiency; and in the third channel, ICT penetration decreases production costs and stimulates demand and investment and thus improves productivity and growth rates. Empirically, there are overwhelming evidences to suggest that ICT is beneficial to economic growth (see e.g. $[25,34-36,52,72-74])$.

On the other hand, empirical studies on the effect of financial development on growth have produced mixed results. Studies such as Adusei [8], Samargandi et al. [66], Adeniyi et al. [5] and Kenza and Eddine [31] find financial development impact negatively on economic growth; Kargbo and Adamu [30], Uddin et al. [71] and Abdulsalam et al. [1] report positive impacts, while the studies of Esso [21], Ductor and Grechyna [18], Yildirim et al. [75] and Adu et al. [7] are inconclusive. Thus, aside the previous theoretical attractions, these empirical controversies are further motivations for the present study. The thesis of this study is to test the importance of ICT diffusion in the finance-growth relationship. This allows us to highlight the role of ICT penetration and diffusion in the financial development and growth nexus in ECOWAS countries in an attempt to bring to logical conclusion the controversies in the findings of related studies such as Andrianaivo and Kpodar [11], Sassi and Goaied [67], Pradhan et al. [51] and Salahuddin and Gow [65].

This study is essentially concerned with accentuating the role ICT diffusion as complementing finance in the growth model. We employ the pooled mean group (PMG) estimator, in comparison with the mean group (MG) and dynamic fixed effect (DFE), on the panel autoregressive distributed lag model. We collect data on 13 ECOWAS countries, with the exception of Cape Verde and Guinea (due to data unavailability), between 2005 and 2016. We are able to showcase findings that underscore the synergy between finance and ICT diffusion for propelling growth. The study is organized into five segments. The first segment is the introduction, while the second segment focuses on the theoretical constructs for this study and the empirical literature. "Methods" section entails the methodology and data requirements. "Results and discussion" section presents the estimation results and discussion with robustness checks. The final section concludes the study and offers policy recommendation.

\section{The literature review \\ Theoretical basis for considering ICT diffusion in the finance-growth nexus}

The theoretical base for this study emanates from the finance-growth theses and the revision of the endogenous growth model to accommodate ICT diffusion as entrenched in the works of Seifallah and Mohamed [67] and Salahuddin and Gow [65]. The link between finance and growth is theoretically established via the supplyleading and the demand-following thesis. These theoretical constructs explain the divergent link to consider finance and growth in an analytical framework: the former tracing the direction of causation from finance to growth, while the latter pinning the development in the financial sector to growth. In the former case, the supply-leading thesis suggests that the causation runs from financial development to economic growth such that a 
well-developed financial sector that minimizes transaction and monitoring costs and asymmetric information is a prerequisite to the process of economic growth $[6$, $22,33,45,68]$. In the latter case, the demand-following hypothesis traces the direction of causation from economic growth to financial development where economic progress grows the demand for financial services to deepen the financial sector (see $[13,70])$. The implication of this theoretical construction is that economic expansion raises the general level of macroeconomic activities that spur the need for expansion of the financial sector.

The role of ICT diffusion in the modelling framework is established via its impact on technical exogenous change in the neoclassical growth theory. In the endogenous growth theory, development stems from investments in human capital and technological development (see $[9,12$, $39,62,63])$. This framework can be modified to view ICT as stimulating economic growth through technological progress which results in productivity growth and thus increases the rate of economic growth of a country and opens up new opportunities for employment (see [15, $65,67])$. It is expected that ICTs will speed up economic growth by fostering innovation processes development and adoption. The authors believe that the theories of endogenous growth model ideas and information generation and distribution as key drivers of economic growth (see $[9,39,63])$. As such, the growth in ICT usage may affect the innovative capacities of the economy through creation of knowledge spill over, development of new products and processes, and business models to promote growth. Consequently, these ICTs usage may accelerate the distribution of ideas and information and foster competition for and development of new products, processes, and business models, thereby further facilitating macroeconomic growth [15].

More relevantly, Seifallah and Mohamed [67] posit that the development of ICT infrastructure consolidates the impact of financial development on economic growth by reducing market imperfections and promoting financial functions: the ICT diffusion reduces the main market frictions which are information and transaction costs. Further, the authors argue that the development of ICT infrastructure eases monitoring and exerting corporate control which is an important function of financial intermediaries [67]. Besides, good ICT infrastructure reduces information asymmetries and price volatility and increases responsiveness of businesses. In passing, given the two channels through which financial development boosts economic growth, through capital accumulation and technological innovation (see [38]), obviously the rapid diffusion of ICT serves as a key driver of economic growth through the technological innovation channel since it contributes to innovation and to the development of new products and processes [65].

\section{Empirical literature review}

The empirical literature in our area of research is polarized first on the nature of relationship (whether positive or negative, linear or nonlinear) between financial development indicators and economic growth; second on the index of financial development for evaluating the nexus; and third on the diversity of intervening variables employed to further probe the finance-growth nexus. There are host of empirical studies in the three categories. In the first category for example, Kargbo and Adamu [30] in Sierra Leone and Uddin et al. [71] in Kenya find evidence that corroborates the finance-led growth hypothesis showing that financial development exerts a significant positive effect on growth. Further, Rafindadi and Yusof [57] investigate the finance-growth nexus and find that financial development stimulates both shortrun and long-run economic growth in Nigeria. The result is, however, mixed in Esso [21] on the validation of supply-led and demand-following hypothesis. This is also the case for Yildirim et al. [75] which provide evidence in support of supply-leading hypothesis for Lithuania, Poland, Romania and Turkey, whereas both demandfollowing and supply-leading hypotheses (bidirectional relationship) were observed for the cases of Bulgaria, Croatia, Hungary and Latvia.

A number of studies could not establish direct relationship. One of such is Ductor and Grechyna [18] who adopt the system generalized method of moments (S-GMM) estimation technique and indicate that the effect of financial development on growth becomes negative, if the rapid growth in private credit is not accompanied by growth in real output. In the same light, Adeniyi et al. [5] find that financial development negatively impacted growth but a sign reversal is shown on accounting for threshold-type effects. In one of the most recent and influential studies in this area of research, Samargandi et al. [66] find evidence of negative short-run effect on growth which may be attributed to too much influence of finance on growth. Improving on the Samargandi, et al. [66] paper, Kenza and Eddine [31] reveal that financial intermediary has a negative effect on the growth rate in MENA countries in both the short and long run. The result of the Hansen threshold technique from Ibrahim and Alagidede [29] reveals that financial development accelerates economic growth, but below 11\% threshold level, finance is largely unresponsive to growth. Ruiz-Vergara [64] with a dynamic panel threshold estimator and Fufa and Kim [23] with GMM technique show that the impact of finance on growth is higher in industrialized countries compared with developing countries. 
The literature is also not unanimous on the choice of proxy for financial development. Adusei [8] employs three measures of financial development, namely domestic credit as a share of GDP, domestic credit to private sector as a share of GDP and broad money supply as a share of GDP, and shows that financial development undermines economic growth in Ghana. Conversely, Adu et al. [7] over a longer period of time, 1961 to 2010, find that the measures of financial development-credit to private sector as ratio to GDP and total domestic credit, are conducive for growth, while broad money stock-toGDP ratio is not growth inducing. Rafindadi and Yusof [54] employed the ratio of liquid liabilities to GDP and the ratio of credit to the private sector by banks to GDP as measures of financial development in addition to trade openness variable, and the result reveals that trade openness and financial development improve economic growth both the long run and the short run in South Africa.

Having over-flogged the finance-growth nexus, the focus of empirical research shifted to the nature of the various intervening variables that increase our understanding of the relationships. Some of the previously examined variables are the roles of human capital, openness, investment flows and technology. Studies in this area are vast. For instance, when Rafindadi and Yusof [55] accounted for the role of trade openness, the findings indicate that although openness hinders economic growth, financial development proxy by liquid liabilities as a ratio of GDP exerts a positive impact on economic growth in Kenya. Rafindadi and Yusof [56] analysed the role of financial development indicators (ratio of liquid liabilities to GDP, ratio of credit to the private sector to GDP and ratio of commercial bank assets to commercial banks and central bank assets) on economic growth in SSA region and found that financial development contributes significantly to economic growth in both the short and long run, while trade openness only has longrun growth-inducing roles. Abdulsalam et al. [1] reveal that the measures of financial development (bank private credit and domestic private credit) contributed significantly to economic growth directly and indirectly via their influence on human capital accumulation.

For Germany, Rafindadi [58] finds that economic growth spurs energy consumption, whereas financial development, capital use and trade openness weaken energy consumption in Germany. Rafindadi and Ozturk [60] also find that financial development, economic growth and trade openness stimulate electricity consumption, while capital stock impedes electricity consumption in Japan. Rafindadi and Aliyu [59] reveal that financial development and trade openness foster long-run but not short-run economic growth in Ghana.
Moradbeigi and Law [42] show that financial development inhibits the adverse influence of oil abundance on economic growth. Rafindadi and Ozturk [61] find that financial development, trade openness and economic growth spur efficient energy use in South Africa. Empirical results from Enowbi et al. [20] indicate that financial instability retards economic growth, while financial liberalization enhances it.

One of the relevant strands of empirical literature relevant here emanates from the theoretical arguments that establish role for ICTs through impact on technology in the endogenous growth model. One of the earlier studies, Koutroumpis [34] reported that information and communication technology has a positive impact on economic growth in the presence of critical mass and infrastructure. Gruber and Koutroumpis [25] also found evidence of significant positive effect of mobile telecommunications diffusion on output growth. $\mathrm{Vu}$ [72] revealed that penetration of personal computers, mobile phones and Internet users had a significant causal effect on growth. Andrianaivo and Kpodar [11], Yazdan and Sadr [74] and Kumar et al. [35, 36] likewise show that the growth impact of ICT is positive and significant. Pradhan et al. [52] find that while the development of telecommunications infrastructure affects economic growth, it is also itself stimulated by growth in the long run.

As a precursor to the present study, Sassi and Goaied [67] indicated that financial development exerted a significant negative effect on economic growth, while ICT diffusion has a positive impact on growth in 17 MENA countries. Pradhan et al. [51] found that both ICT infrastructure and financial development are important in the determination of long-run economic growth. Further, Salahuddin and Gow [65] found long-run relationships among Internet usage, financial development and trade openness on economic growth and that Internet usage and financial development have significant positive effects on economic growth in the long run. Kumar et al. $[35,36]$ confirm long-run relationship between ICT and economic growth, and Hofman et al. [28] show that investment in ICT improves economic growth. Latif et al. [37] discovered that ICT, FDI and international trade contribute positively to economic growth. Like the conclusion of Fufa and Kim [23] on the role of finance on growth, Niebel [44] reveals that ICT contributes significantly to growth in developed countries than in developing countries. More recently, Pradhan et al. [53] found that ICT infrastructure enhances economic growth where a unidirectional causality runs from ICT infrastructure to economic growth. Based on these foundations, the present study improves on the theoretical and methodological standpoints to consider ICTs, finance and economic growth in a unified framework. 


\section{Methods}

\section{The model and estimation technique}

The empirical model to examine the role of ICT diffusion in the finance-growth nexus is specified as:

$$
\mathrm{GR}_{i t}=\sigma_{i}+\beta \mathrm{FIN}_{i t}+\phi \mathrm{ICTI}_{i t}+\delta \mathrm{TOP}_{i t}+\mu_{i t}
$$

where the variables are defined as growth rate of gross domestic product (GR), country-specific intercept $(\sigma)$, financial development measured by credit to private sector as ratio of GDP (FIN), ICT diffusion index (ICTI) and degree of openness of the individual economies (TOP) and $\mu_{i t}$ is the error term, while $t$ is the time period and $i$ symbolizes the country.

In order to investigate the role of ICT diffusion in the finance-growth nexus, we employ the panel autoregressive distributive lag model (PARDL) approach of Pesaran et al. [50] because the panel ARDL estimation technique is efficient in the face of $I(0)$ and or $I(1)$ variables, and it generates consistent estimates in the presence of endogeneity [50]. In addition, the panel ARDL technique considers the heterogeneity of the dynamic panel setting, the short-run dynamic and the long-run equilibrium of the model [10, 16, 66]. Lastly, panel ARDL approach estimates the short-run and long-run effects simultaneously (see [50]).

Panel autoregressive distributed lag (ARDL) $(p, q)$ is specified as follows:

$$
\begin{aligned}
\mathrm{GR}_{i, t}= & \sigma_{i}+\sum_{m=1}^{p} \delta_{i m} \mathrm{GR}_{i, t-m}+\sum_{m=0}^{q} \varphi_{i m}^{\prime} Z_{i, t-m} \\
& +\mu_{i t} ; Z_{i, t}=\left(\mathrm{FIN}_{i, t}, \mathrm{ICTI}_{i, t}, \mathrm{TOP}_{i, t}\right),
\end{aligned}
$$

where $t=1,2,3 \ldots T$ indicates the time dimension (annual) and $i=1,2, \ldots, N$ indicates the cross-sectional unit. In addition, $m$ represents the number of time lags. In Eq. (3.2), $\mathrm{GR}_{i, t}$ represents the growth rate of gross domestic product for i countries and t period, GR as dependent variable; the vector $Z_{i, t}$ includes the key explanatory variables: financial development measured by credit to private sector (FIN), ICT diffusion index (ICTI) as well as a degree of openness (TOP) and $\sigma_{i}$ denotes country fixed effects. Equation (3.2) can be re-parameterized into

$$
\begin{aligned}
\Delta \mathrm{GR}_{i, t}= & \sigma_{i}+\theta_{i} y_{i, t-m}+\phi_{i}^{\prime} Z_{i, t}+\sum_{m=1}^{p} \delta_{i j} \mathrm{GR}_{i, t-m} \\
& +\sum_{m=0}^{q} \varphi_{i j}^{\prime} Z_{i, t-m}+\mu_{i t}
\end{aligned}
$$

$$
\begin{aligned}
\theta_{i} & =-1\left(1-\sum_{m=1}^{p} \delta_{i m}\right) \\
\phi_{i} & =\frac{\sum_{m=0}^{q} \varphi_{i m}}{\left(1-\sum_{m=1}^{p} \delta_{i m}\right)}, \\
\delta_{i m}^{*} & =-\sum_{j=m+1}^{p} \delta_{i m} \text { and } \varphi_{i m}^{*}=-\sum_{j=m+1}^{q} \varphi_{i m} .
\end{aligned}
$$

Error correction model of Eq. (3.3) in level forms can be specified as:

$$
\begin{aligned}
\Delta \mathrm{GR}_{i, t}= & \sigma_{i}+\theta_{i}\left(y_{i, t-m}-\phi_{i}^{\prime} Z_{i, t}\right)+\sum_{m=1}^{p} \delta_{i m} \mathrm{GR}_{i, t-m} \\
& +\sum_{m=0}^{q} \varphi_{i m}^{\prime} Z_{i, t-m}+\mu_{i t} ; \quad \phi_{i}<0
\end{aligned}
$$

where $\theta_{i}\left(y_{i, t-m}-\phi_{i}^{\prime} Z_{i, t}\right)$ is the adjustment in growth rate of gross domestic product to the deviation from its long-run relationship with the explanatory variables. In addition, $\delta_{i m}^{*}$ and $\varphi_{i m}^{*}$ are short-run coefficients connecting with its lag values and with determinants $Z_{i t}$ vectors. Lastly, the error correction coefficient $\theta_{i}$ estimates the speed of adjustment of $\mathrm{GR}_{i, t}$ towards its long-run equilibrium ensuing a change in $Z_{i t}$. The condition $\theta_{i}<0$ ensures that a long-run relation exists. Therefore, a significant and negative value of $\theta_{i}$ is regarded as evidence of cointegration between $\mathrm{GR}_{i, t}$ and $Z_{i t}$.

Equation (3.6) can be estimated by three estimators of panel ARDL framework, namely the dynamic fixed effect (DFE), the pooled mean group (PMG) and the mean group (MG). The dynamic fixed effect (DFE) technique assumes all slope coefficients (both short run and long run) to be homogeneous across countries except the intercepts. It incorporates the lagged term of the dependent variable as one of the independent variables. The second estimator which is the mean group (MG) estimator was developed by Pesaran and Smith [49], and it allows both short-run and long-run coefficients and the intercepts to differ across countries. It estimates the long-run parameters by taking an average of the long-run coefficients of each cross section. The third estimator is the pooled mean group (PMG) estimator proposed by Pesaran et al. [50] which is an intermediate estimator between DFE and MG. It allows the long-run coefficient to be homogeneous across countries, while the short-run coefficients and the lag of the error correction term are heterogeneous across countries. 


\section{Data and preliminary analysis}

The data requirement for this study involves information on financial development, ICT and economic growth in 13 ECOWAS countries: Nigeria, Gambia, Ghana, Benin, Côte d'Ivoire, Guinea-Bissau, Liberia, Mali, Sierra Leone, Burkina Faso, Niger, Senegal and Togo spanning 2005 to 2016. The exclusion of Cape Verde and Guinea is due to the unavailability of data on the countries for the variables in the study. The choice of the time frame is justified given that information and communication technologies such as computers, mobile phones, Internet, ATMs, POS machines and other electronic outlets penetrated into West Africa around the early 2000s. The variables used in this study are as follows. The dependent variable is the growth rate of gross domestic product (gr), while the independent variables are financial development measured by credit to private sector as a ratio of GDP (FIN) in line with Rafindadi and Yusof [54-57] and Rafindadi and Ozturk [61] and for robustness, measured as broad money supply (BMS) (see [1, 7, 47, 66]).

We employ the principal component analysis (PCA) on WDI data on mobile cellular subscription per 100 people, fixed telephone subscription per 100 people, and secure Internet server per $1,000,000$ people to extract the index of ICT diffusion for ECOWAS countries. The PCA is a statistical technique that is used to generate fewer numbers of variables or an index that explains most of the variations in the original variables (see $[4,46]$ ). Another

\section{Table 1 Descriptive statistics}

\begin{tabular}{lccrrr}
\hline Variable & Obs & Mean & SD & \multicolumn{1}{l}{ Min } & \multicolumn{1}{l}{ Max } \\
\hline GR & 156 & 4.7436 & 3.7725 & -20.4928 & 20.7157 \\
FIN & 156 & 15.9171 & 8.0854 & 1.3458 & 39.2841 \\
ICTI & 156 & $3.26 \mathrm{E}-08$ & 1.2903 & -4.2836 & 2.3526 \\
TOP & 156 & 73.7225 & 38.8907 & 21.1243 & 311.3553 \\
\hline
\end{tabular}

Gr, FIN, ICT and TOP represent growth rate of gross domestic product, financial development measured by credit to private sector as a ratio of GDP, information and communication technology index and degree of openness important variable worthy of inclusion is the degree of openness (TOP) measured by total trade (exports plus imports) as a ratio of GDP which can account for the integration of ECOWAS countries with the developed countries. All the data are sourced from the 2018 World Development Indicators (WDI), the data set of the World Bank. Selected 13 ECOWAS countries for this study are based on data availability and are presented in "Appendix 1", while "Appendix 2" entails measurements and definitions of variables employed for this study.

As a quick check, we take a cursory look at our data. Table 1 presents the descriptive statistics of our data. These include the mean, standard deviation, minimum and maximum. The results indicate that the average of the growth rate of gross domestic product, financial development (proxied by credit to private sector as a ratio of GDP), ICT index and degree of openness (proxied by total trade as a ratio of GDP) are equal to 4.74 , $15.91,0.32$ and 73.72, respectively, while the standard deviation values signify high variability in the series.

\section{Results and discussion}

\section{Panel unit root tests}

The time-series nature of our data set makes our variables susceptible to unit root process. We therefore employ the Breitung, Im, Pesaran and Shin (IPS) and Hadri tests to test for the presence of the unit roots in the panel data and determine the order of integration of the series. After estimation, the three unit root techniques yield identical results as shown in Table 2 . The results show that growth rate of gross domestic product (GR) does not have unit root, i.e. it is stationary at level $[I(0)]$ at $1 \%$ significance level. All the other variables, namely financial development (FD), ICT index (ICTI) and degree of openness (TOP), are only stationary at first difference at $1 \%$ significance level. The foregoing outcome lends credence to the adoption of panel ARDL methodology as there are no integrated of order two $[I(2)]$ variables in the model.

Table 2 Panel unit root test

\begin{tabular}{|c|c|c|c|c|c|c|}
\hline \multirow[t]{2}{*}{ Variables } & \multicolumn{2}{|c|}{ Breitung test } & \multicolumn{2}{|l|}{ IPS test } & \multicolumn{2}{|l|}{ Hadri test } \\
\hline & Level & First Diff & Level & First Diff & Level & First Diff \\
\hline GR & $-3.8384^{* * *}$ & $-4.7332^{* * *}$ & $-3.0755^{* * *}$ & $-5.7087^{* * *}$ & $1.8027^{* *}$ & $-2.2789^{* * *}$ \\
\hline FIN & 2.3133 & $-5.3164^{* *}$ & 1.3541 & $-3.9961^{* * *}$ & $12.9999^{* * *}$ & 0.6378 \\
\hline$|C T|$ & 3.7598 & $-1.6821^{* * *}$ & $-2.9594^{* * *}$ & $-6.0751^{* * *}$ & $18.3911^{* * *}$ & -0.1748 \\
\hline TOP & -1.1951 & $-4.3387^{* * *}$ & 0.3671 & $-3.4774^{* * *}$ & $12.5738^{* * *}$ & 0.0709 \\
\hline
\end{tabular}

Gr, FIN, ICT and TOP represent growth rate of gross domestic product, financial development measured by credit to private sector as a ratio of GDP, information and communication technology index and degree of openness

******* ${ }^{*}$ Statistical significance at $1 \%, 5 \%$ and $10 \%$, respectively. The null hypotheses of Breitung and Im, Pesaran and Shin (IPS) tests are that the underlying series are non-stationary, while the Hadri null is that the series is stationary 


\section{The short- and long-run estimation results}

In order to assess the short-run and long-run effects of information and communication technology diffusion and financial development on economic growth, we estimate the ARDL-based mean group (MG), dynamic fixed effect (DFE) and pooled mean group (PMG) methods. The results are reported in Table 3. From the estimated results, the Hausman test failed to reject the long-run homogeneity restrictions, which indicates that PMG is a more efficient estimator than either the MG or DFE. For this reason, our discussion only focuses on the PMG results. As expected, the error correction term of the model is negative and significant, thereby suggesting convergence to long-run equilibrium. More specifically, the coefficients indicated that the system instantaneously reverts to its long-run equilibrium following a shock that diverts its path away from steady state.

\section{Table 3 Panel ARDL regression result}

\begin{tabular}{|c|c|c|c|}
\hline Variables & PMG & MG & DFE \\
\hline \multicolumn{4}{|l|}{ Long-run estimate } \\
\hline \multirow[t]{2}{*}{ Fin } & $-0.213^{* * *}$ & $-2.530^{*}$ & 0.0170 \\
\hline & $(0.0430)$ & $(1.369)$ & $(0.118)$ \\
\hline \multirow[t]{2}{*}{$\mid \mathrm{ICTI}$} & $-1.642^{* * *}$ & -4.217 & -0.970 \\
\hline & $(0.241)$ & $(4.811)$ & $(0.773)$ \\
\hline \multirow[t]{2}{*}{ Fin $\times I C T I$} & $0.126^{* * *}$ & $0.782^{*}$ & 0.0628 \\
\hline & $(0.0130)$ & $(0.442)$ & $(0.0552)$ \\
\hline \multirow[t]{2}{*}{ Top } & $0.0536^{* * *}$ & 0.179 & 0.0213 \\
\hline & $(0.0147)$ & $(0.201)$ & $(0.0202)$ \\
\hline \multicolumn{4}{|l|}{ Short-run estimate } \\
\hline \multirow[t]{2}{*}{$\mathrm{ECT}$} & $-0.953^{* * *}$ & $-0.947^{* *}$ & $-0.862^{* * *}$ \\
\hline & $(0.141)$ & $(0.395)$ & $(0.0909)$ \\
\hline \multirow[t]{2}{*}{$\Delta$ Fin } & -1.207 & -2.695 & -0.116 \\
\hline & $(1.224)$ & $(2.434)$ & $(0.126)$ \\
\hline \multirow[t]{2}{*}{$\triangle \mathrm{ICTI}$} & 84,597 & 156,200 & 0.659 \\
\hline & $(84,588)$ & $(156,195)$ & $(1.820)$ \\
\hline \multirow[t]{2}{*}{$\Delta$ Fin $\times$ ICTI } & -1.024 & -1.447 & 0.0199 \\
\hline & $(1.331)$ & $(1.685)$ & $(0.0960)$ \\
\hline \multirow[t]{2}{*}{$\Delta \mathrm{Top}$} & -0.0207 & 0.0922 & 0.0214 \\
\hline & $(0.0783)$ & $(0.129)$ & $(0.0242)$ \\
\hline \multirow[t]{2}{*}{ Constant } & 54,948 & 101,472 & 2.100 \\
\hline & $(54,946)$ & $(101,456)$ & $(1.967)$ \\
\hline No. of observations & 156 & 156 & 156 \\
\hline No. of countries & 13 & 13 & 13 \\
\hline Hausman test & MG versus PMG & & MG versus DFE \\
\hline Chi2 (4) & 0.92 & & 0.78 \\
\hline Prob & 0.9215 & & 0.9409 \\
\hline
\end{tabular}

GR, FIN, ICT and TOP represent growth of gross domestic product, financial development measured by credit to private sector as a ratio of GDP, information and communication technology index and degree of openness

$* * *, * *,{ }^{*}$ Statistical significance at $1 \%, 5 \%$ and $10 \%$, respectively; values in () are standard errors. Hausman test indicates that PMG is consistent and efficient estimation than MG and DFE estimation
The results indicate that ICT diffusion has a significant negative impact on economic growth in the long run, but it exerts no impact on economic growth in the short run. Thus, a unit increase in ICT diffusion would be expected to impede economic growth in ECOWAS countries by 1.64 points in the long run. Further, results seem to suggest that financial development retards growth in ECOWAS countries in the short and long run. This result negates the findings of many scholars in the economic literature (e.g. [25, 34-36, 52, 54, 71-75]). However, this outcome validates the findings of Ductor and Grechyna [18], Adusei [8] in Ghana, Samargandi et al. [66] in middle-income countries, Adeniyi et al. [5] in Nigeria and Kenza and Eddine [31] in MENA countries. Less importantly, the coefficient of trade openness (DOP) is positive and significant in the long run signifying the growth benefits of economic openness to the focused economies, in confirmation of the findings of Rafindadi and Yusof [55] and Rafindadi and Aliyu [59].

Interestingly, when we interact ICT diffusion with financial development, we obtain only a long-run positive and significant impact on economic growth. This implies that the combination of ICT and financial development is required to bring about improvement in economic performance of ECOWAS countries. This result is in tune with previous empirical evidences such as Abdulsalam et al. [1] and Rafindadi and Aliyu [59] who establish the growth impact of financial development through the roles of other intervening variables such as human capital development and trade openness and a host of studies that find the positive and significant growth impact of ICT [11, 23, 28, 34-37, 44, 52, 53, 72, 74]. More strikingly, our results support previous findings by Sassi and Goaied [67], Pradhan et al. [51] and Salahuddin and Gow [65], suggesting that ICT diffusion positively influences financial development to spur economic growth. These studies are, however, significantly different from the present essentially in terms of better methodology, the area of study and robust treatment of the issues by comparing alternative measures of financial development and inventing an ICT diffusion index has done in our study.

\section{Robustness checks}

There are various proxies for measuring financial development in the literature. In the main analysis, we align with the choice of credit to private sector as a ratio of GDP to measure financial development in line with Rafindadi and Yusof [54-57] and Rafindadi and Ozturk [61]. The argument in support of our choice rests on the reasoning that funding for the private sectors' productive activities will boost economic growth than other known measures of financial development. For sensitivity, however, we use broad money supply as a ratio of 
GDP (as informed by Adu et al. [7], Abubakar et al. [3], Samargandi et al. [66], Ono [47]) instead of credit to private sector to confirm our result. This is one of the major strengths of the present study over and above the previous papers. Table 4 reports the panel ARDL result on financial development (proxied by broad money supply as a ratio of GDP) and ICT diffusion on economic growth. We find that the result is not sensitive to the different choice of financial development variable, especially for the positive long-run impact of ICT diffusion and financial development on economic growth.

\section{Conclusion}

This study further extended the finance-growth nexus by examining the role of ICT diffusion in the relationship using a dynamic panel modelling framework. One of the major findings that emanate from this study aligns with

\section{Table 4 Panel ARDL regression result}

\begin{tabular}{|c|c|c|c|}
\hline Variables & PMG & MG & DFE \\
\hline \multicolumn{4}{|l|}{ Long-run estimate } \\
\hline \multirow[t]{2}{*}{ BMS } & $-0.192^{* * *}$ & -2.472 & 0.0759 \\
\hline & $(0.0541)$ & $(1.566)$ & $(0.0742)$ \\
\hline \multirow[t]{2}{*}{ ICTI } & $-1.489^{* * *}$ & 23.30 & -0.359 \\
\hline & $(0.568)$ & (31.98) & $(1.003)$ \\
\hline \multirow[t]{2}{*}{$\mathrm{BMS} \times \mid \mathrm{CTI}$} & $0.0992^{* * *}$ & -0.706 & 0.00850 \\
\hline & $(0.0240)$ & $(1.188)$ & $(0.0263)$ \\
\hline \multirow[t]{2}{*}{ TOP } & 0.0381 & 0.352 & 0.0261 \\
\hline & $(0.0239)$ & $(0.376)$ & $(0.0192)$ \\
\hline \multicolumn{4}{|l|}{ Short-run estimate } \\
\hline \multirow[t]{2}{*}{ ECT } & $-0.679^{* * *}$ & $-0.613^{*}$ & $-0.863^{* * *}$ \\
\hline & $(0.143)$ & $(0.360)$ & $(0.0891)$ \\
\hline \multirow[t]{2}{*}{ BMS } & -0.533 & -0.633 & $-0.275^{* * *}$ \\
\hline & $(0.366)$ & $(0.889)$ & $(0.105)$ \\
\hline \multirow[t]{2}{*}{ ICTI } & 116,291 & 290,125 & 1.974 \\
\hline & $(116,282)$ & $(290,100)$ & $(1.932)$ \\
\hline \multirow[t]{2}{*}{$\mathrm{BMS} \times|\mathrm{ICT}|$} & -0.267 & -0.962 & -0.0335 \\
\hline & $(0.238)$ & $(0.940)$ & $(0.0532)$ \\
\hline \multirow[t]{2}{*}{ TOP } & 0.0671 & 0.272 & 0.0233 \\
\hline & $(0.0712)$ & $(0.200)$ & $(0.0237)$ \\
\hline \multirow[t]{2}{*}{ Intercept } & 75,539 & 188,448 & 0.478 \\
\hline & $(75,533)$ & $(188,441)$ & $(2.334)$ \\
\hline No. of observations & 156 & 156 & 156 \\
\hline No. of countries & 13 & 13 & 13 \\
\hline Hausman test & MG versus PMG & & MG versus DFE \\
\hline Chi2 (4) & 0.14 & & 0.19 \\
\hline Prob & 0.9977 & & 0.9958 \\
\hline
\end{tabular}

Gr, FIN, ICT and TOP represent growth of gross domestic product, financial development measured by broad money supply as a ratio of GDP, information and communication technology index and degree of openness

$* * *, * *,{ }^{*}$ Statistical significance at $1 \%, 5 \%$ and $10 \%$, respectively; values in () are standard errors. Hausman test indicates that PMG is consistent and efficient estimation than MG and DFE estimation a group of previous studies that financial development exerts negative impacts on economic growth of ECOWAS. This finding implies that financial sector development efforts in the ECOWAS countries are not well positioned to achieve the intended goals. To improve on this weakness, we pursue a number of theoretical and methodological innovations. Theoretically, we account for the role ICTs to complement the financial policies in the pursuit of economic growth objective. Methodologically, we employed a robust estimation technique that affords us stronger estimates for the short and long run; we constructed an ICT diffusion index in place of a single proxy; and compare results for alternative measures of financial development. Leaning on the following strengths, we conclude that there is need for greater investment in ICTs in ECOWAS countries to mitigate the negative finance-growth nexus given the empirical result which suggests that ICT diffusion positively influences financial development to spur economic growth. The reality of this situation for the West African region is that financial sector development efforts have to be strengthened by ICT infrastructure, improved Internet penetration and further integration of electronic finance policies.

\section{Policy recommendations}

The proceeds of this study are intuitive for harmonizing financial sector and innovative reforms in the area of study. The major finding of the study revealed that financial development on its own inhibits growth of ECOWAS countries; however, its interaction with ICT diffusion promotes economic growth in the region. Thus, we recommend that the ECOWAS countries should target improved ICTs investment, penetration and affordability to complement their financial sector development efforts via increased investment in ICT infrastructure, improved Internet penetration and further integration of electronic finance systems. These ICT policy actions will serve as antidote for the negative impact of financial development indicators on economic growth in the area of study.

\section{Abbreviations \\ ICT: Information and communication technology; ICTI: Information and communication technology index; ECOWAS: Economic Community of West African States; MG: Mean group; DFE: Dynamic fixed effect; PMG: Pooled mean group; ARDL: Autoregressive distributed lag (ARDL); IPS: Im, Pesaran and Shin; Gr: Growth rate of gross domestic product; FIN: Financial development; TOP: Trade openness; BMS: Broad money supply.}

\section{Acknowledgements}

The authors appreciate the editor for his/her useful comments on the paper.

Authors' contributions

ASA did the write-up, collected the data and analysed the result, while IAA drafted the review of literature and participated actively in conducting 
analyses, editing and approving the final submitted version of the manuscript. Both authors read and approved the final manuscript.

\section{Funding}

There is no funding for this study.

\section{Availability of data and materials}

The data sets for this study are sourced from World Development Indicator (WDI) database of World Bank of 2017 edition and are available upon request.

\section{Competing interests}

There are no competing interests for this research work.

\section{Author details}

${ }^{1}$ Department of Economics, Obafemi Awolowo University, lle-lfe, Osun State, Nigeria. ${ }^{2}$ Centre for Econometric and Allied Research, University of Ibadan, Ibadan, Oyo State, Nigeria.

\section{Appendix 1: List of the sample ECOWAS countries (13)}

\begin{tabular}{ll}
\hline Nigeria & Mali \\
Gambia & Sierra Leone \\
Ghana & Burkina Faso \\
Benin & Niger \\
Côte d'Ivoire & Senegal \\
Guinea-Bissau & Togo \\
Liberia & \\
\hline
\end{tabular}

\section{Appendix 2: Variable measurement and sources}

\begin{tabular}{|c|c|c|}
\hline Variables & Measurement & Source \\
\hline Economic growth (GR) & Growth rate of GDP (\%) & WDI, 2017 \\
\hline \multicolumn{3}{|l|}{$\begin{array}{l}\text { Info. and comm. tech. index } \\
\text { (ICTI) }\end{array}$} \\
\hline Mobile penetration (MCS) & $\begin{array}{l}\text { Mobile cellular subscription } \\
\text { per } 100 \text { people }\end{array}$ & WDI, 2017 \\
\hline Fixed telephone (FTS) & $\begin{array}{l}\text { Fixed telephone subscription } \\
\text { per } 100 \text { people }\end{array}$ & 2017 \\
\hline Secure internet server (IS) & $\begin{array}{l}\text { Secure Internet server per } \\
1,000,000 \text { people }\end{array}$ & WDI, 2017 \\
\hline Financial development (FIN) & $\begin{array}{l}\text { Domestic credit to private } \\
\text { sector (\%of GDP) }\end{array}$ & WDI, 2017 \\
\hline Financial development (BMS) & Money supply (\% of GDP) & WDI, 2017 \\
\hline Degree of openness (TOP) & Trade (\% of GDP) & WDI, 2017 \\
\hline
\end{tabular}

Received: 19 February 2020 Accepted: 26 February 2020

Published: 27 March 2020

\section{References}

1. Abdulsalam A, Salina HJK, Mohammed BY (2015) Financial development, human capital accumulation and economic growth: evidence from the economic community of West African States. Procedia Soc Behav Sci 172:96-103

2. Abu-Bader S, Abu-Qarn AS (2008) Financial development and economic growth: the Egyptian experience. J Policy Modell 30:887-898
3. Abubakar A, Kassim SH, Yusoff MB (2015) Financial development, human capital accumulation and economic growth: empirical evidence from the economic community of West African States (ECOWAS). Procedia Soc Behav Sci 172:96-103

4. Achia TNO, Wangombe A, Khadoli N (2010) A logistics regression model to identify key determinants of poverty using demographic and health survey data. Eur J Soc Sci 13(1):456-471

5. Adeniyi O, Oyinlola A, Omisakin O, Egwaikhide FO (2015) Financial development and economic growth in Nigeria: evidence from threshold modelling. Econ Anal Policy 47:11-21

6. Adeyeye PO, Fapetu O, Aluko OA, Migiro SO (2015) Does supply-leading hypothesis hold in a developing economy? A Nigerian focus. Procedia Econ Finance 30:30-37

7. Adu G, Marbuah G, Mensah JT (2013) Financial development and economic growth in Ghana: does the measure of financial development matter? Rev Dev Finance 3:192-203

8. Adusei S (2013) Financial development and economic growth: evidence from Ghana. Int J Bus Finance 7:61-76

9. Aghion P, Howitt P (1998) Endogenous growth theory. MIT Press, Cambridge

10. Ahmed A, Uddin GS, Sohag K (2016) Biomass energy, technological progress and the environmental Kuznets curve: evidence from selected European countries. Biomass Bioenerg 90:202-208

11. Andrianaivo M, Kpodar K (2011) ICT, financial inclusion, and growth: evidence from African countries. International Monetary Fund Working Paper 11/73

12. Barro R (1998) Determinants of economic growth: a cross-country empirical study. MIT Press, Cambridge

13. Calderón C, Liu L (2002) The direction of causality between financial development and economic growth (Central Bank of Chile Working Paper No. 184). Santiago: Central Bank of Chile

14. Carmen S (2015) Dynamics of ICT development in the EU. Econ Finance 23:513-520

15. Czernich N, Falck O, Kretschmer T, Woessmann L (2011) Broadband infrastructure and economic growth. Econ J 121:505-532

16. Demetriades P, Law SH (2006) Finance, institutions and economic growth. Int J Finance Econ 11(3):245-260

17. Dimelisa PS, Papaioannou KS (2010) FDI and ICT effects on productivity growth: a comparative analysis of developing and developed countries. Eur J Dev Res 22:79-96

18. Ductor L, Grechyna D (2012) Financial development, real sector, and economic growth. Int Rev Econ Finance 37:393-405

19. Elene K (2013) Five ways technology can help the economy. World Economic Forum. https://www.weforum.org/agenda/2013/04/five-waystechnology-can-help-the-economy/. Accessed 10 Sept 2018

20. Enowbi MB, Mlambo K, Asongu S (2017) Linkages between financial development, financial instability, financial liberalization and economic growth in Africa. Res Int Bus Finance 45:168-179

21. Esso $\sqcup J$ (2010) Cointegrating and causal relationship between financial development and economic growth in ECOWAS countries. J Econ Int Finance 2:036-048

22. Fosu SB (2013) Financial development and economic growth in Africa: a dynamic causal relationship (Master of Arts in Economics Dissertation). University of New Hampshire, New Hampshire

23. Fufa T, Kim J (2018) Stock markets, banks, and economic growth: evidence from more homogeneous panels. Res Int Bus Finance 44(504):517

24. Goldsmith RW (1969) Financial structure and development. Yale, New Haven, CT

25. Gruber H, Koutroumpis P (2010) Mobile communications: diffusion facts and prospects. J Commun Strateg 77(1):133-145

26. Gurley JG, Shaw ES (1955) Financial aspect of the economic development. Am Econ Rev XIV(4):461-473

27. Hector C, Salvador E, Emigdio L (2016) The effects of ICTs as innovation facilitators for a greater business performance: evidence from Mexico. Procedia Comput Sci 91:47-56

28. Hofman A, Aravena C, Aliaga V (2016) Information and communication technologies and their impact in the economic growth of Latin America, 1990-2013. Telecommun Policy 40(5):485-501

29. Ibrahim M, Alagidede P (2017) Nonlinearities in financial developmenteconomic growth Nexus: evidence from sub-Saharan Africa. Res Int Bus Finance 20:311-325 
30. Kargbo SM, Adamu PA (2009) Financial development and economic growth in Sierra Leone. J Monet Econ Integr 9:30-61

31. Kenza M, Eddine NS (2016) The effect of the financial sector development on growth: the case of the MENA countries. Arab Econ Bus J 11:72-85

32. Khuong MV (2011) ICT as a source of economic growth in the information age: empirical evidence from the 1996-2005 period. Telecommun Policy 35:357-372

33. King RG, Levine R (1993) Finance and growth: Schumpeter might be right. Q J Econ 108(3):717-737

34. Koutroumpis $P$ (2009) The economic impact of broadband on growth: a simultaneous approach. Telecommun Policy 33(9):471-485

35. Kumar RR, Kumar RD, Patel A (2015) Accounting for telecommunications contribution to economic growth: a study of small Pacific Island State. Telecommun Policy 39(3-4):284-295

36. Kumar RR, Stauvermann PJ, Samitas A (2015) The effects of ICT on Output per worker: a study of the Chinese economy. Telecommun Policy 40(2):102-115

37. Latif Z, Mengke $Y$, Ximei L, Pathan ZH, Salam S, Jianqiu Z (2017) The dynamics of ICT, foreign direct investment, globalization and economic growth: panel estimation robust to heterogeneity and cross-sectional dependence. Telematics Inform 35(2):318-328

38. Levine R (1997) Financial development and economic growth: views and agenda. J Econ Lit 35(2):688-726

39. Lucas R (1988) On the mechanics of economic development. J Monet Econ 22(1):3-42

40. McKinnon RI (1973) Money and capital in economic development. Brookings Institution, Washington

41. Michael S, Mneria E, Ogoti T, Bernard N (2014) Investigation of information communication technology in Kenyan Primary Education Sector. J Emerg Trends Comput Inf Sci 5(7):213-225

42. Moradbeigi M, Law SH (2017) The role of financial development in the oil-growth nexus. Resour Policy 53:164-172

43. Ndombi RM, Wakhungu AN, Mutongwa SM (2014) Analysis of ICT and management systems in driving world economy. Int J Acad Res Bus Soc Sci 4(10):224-259

44. Niebel T (2018) ICT and economic growth—comparing developing, emerging and developed countries. World Dev 104:197-211

45. Odhiambo NM (2008) Financial development in Kenya: a dynamic test of the finance led growth hypothesis. Econ Issues 13(2):21-36

46. Olofin OP (2013) Defence spending and poverty reduction in Nigeria. Am J Econ 2(6):122-127

47. Ono S (2017) Financial development and economic growth nexus in Russia. Russ J Econ 3:321-332

48. Osabuohien ES (2008) ICT and Nigerian banks reforms: analysis of anticipated impacts in selected banks. Glob J Bus Res 2(2):67-76

49. Pesaran $H$, Smith R (1995) Estimating long-run relationships from dynamic heterogeneous panels. J Econom 68(1):79-113

50. Pesaran MH, Shin Y, Smith RP (1999) Pooled mean group estimation of dynamic heterogeneous panels. J Am Stat Assoc 94(446):621-634

51. Pradhan RP, Arvin MB, Norman NR (2015) The dynamics of information and communications technologies infrastructure, economic growth and financial development: evidence from Asian countries. Technol Soc 42:135-149

52. Pradhan RP, Arvin MB, Norman NR, Bele SK (2014) Economic growth and the development of telecommunications infrastructure in the $\mathrm{G}-20$ countries: a panel-VAR approach. Telecommun Policy 38:634-649

53. Pradhan RP, Mallik G, Bagchi TP (2018) Information communication technology (ICT) infrastructure and economic growth: a causality evinced by cross-country panel data. IIMB Manag Rev 30:91-103

54. Rafindadi AA, Yusof Z (2013) Is Financial development a factor to the leading growth profile of the South African Economy? Measuring and uncovering the hidden secret. Int J Econ Empir Res 1(9):99-112

55. Rafindadi AA, Yusof Z (2013) A startling new empirical finding on the nexus between financial development and economic growth in Kenya. World Appl Sci J 28:147-161
56. Rafindadi AA, Yusof Z (2013c) An application of panel ARDL in analyzing the dynamics of financial development and economic growth in $38 \mathrm{sub}$ Saharan African continents. In: Proceeding —Kuala Lumpur International Business, Economics a Law Conference, p 2, Malaysia

57. Rafindadi AA, Yusof Z (2015) Do the dynamics of financial development spur economic growth in Nigeria's contemporal growth struggle? A fact beyond the figures. Qual Quant Int J Methodol 49:365-384

58. Rafindadi AA (2015) Econometric prediction on the effects of financial development and trade openness on the German energy consumption: a startling revelation from the data set. Int J Energy Econ Policy 5(1):182-196

59. Rafindadi AA, Aliyu AA (2017) Growing the growth of the Ghanaian economy: is the function of the country's financial development of any significance? Asian Econ Financ Rev 7(2):206-221

60. Rafindadi AA, Ozturk I (2016) Effects of financial development, economic growth and trade on electricity consumption: evidence from post-Fukushima Japan. Renew Sustain Energy Rev 54:1073-1084

61. Rafindadi AA, Ozturk I (2017) Dynamic effects of financial development, trade openness and economic growth on energy consumption: evidence from South Africa. Int J Energy Econ Policy 7(3):74-85

62. Romer PM (1986) Increasing returns and long run growth. J Polit Econ 94(5):1002-1037

63. Romer PM (1990) Endogenous technological change. J Polit Econ 98(5):71-102

64. Ruiz-Vergara J (2017) Financial development, institutional investors, and economic growth. Int Rev Econ Finance 54:218-224

65. Salahuddin M, Gow J (2015) The effects of internet usage, financial development and trade openness on economic growth in South Africa: a time series analysis. J Telemat Inform 33(4):1141-1154

66. Samargandi N, Fidrmuc J, Ghosh S (2015) Is the relationship between financial development and economic growth monotonic? Evidence from a sample of middle-income countries. World Dev 68:66-81

67. Sassi S, Goaied M (2013) Financial development, ICT diffusion and economic growth: lessons from MENA region. Telecommun Policy 37:252-261

68. Schumpeter JA (1911) The theory of economic development. Harvard University Press, Cambridge

69. Shaw ES (1973) Financial deepening in economic development. Oxford University Press, New York

70. Singh A (1999) Should Africa promote stock market capitalism. J Int Dev 11:343-365

71. Uddin GS, Sjo B, Shahbaz M (2013) The causal nexus between financial development and economic growth in Kenya. Econ Model 35:701-707

72. Vu KM (2011) ICT as a source of economic growth in the information age: empirical evidence from the 1996-2005 period. Telecommun Policy 35(4):357-372

73. Vu KM (2013) Information and communication technology (ICT) and Singapore's economic growth. Inf Econ Policy 25:284-300

74. Yazdan GF, Sadr SM (2013) FDI and ICT effects on productivity growth Procedia Soc Behav Sci 93:1710-1715

75. Yildirim SO, Ozdemir BK, Dogan B (2013) Financial development and economic growth nexus in emerging European economies: evidence from asymmetric causality. Int J Econ Financ Issues 3(3):710-722

\section{Publisher's Note}

Springer Nature remains neutral with regard to jurisdictional claims in published maps and institutional affiliations. 